\title{
An Analysis of Identification of Students' Need in Learning English at Marketing Department of SMK Negeri 1 Kolaka
}

\author{
${ }^{1}$ Ray Suryadi, ${ }^{2}$ Hendra \\ Universitas Sembilanbelas November Kolaka \\ *Corresponding Author \\ Email: ray_suryadi@yahoo.com
}

\begin{abstract}
This research is aimed to answer the problem of the research "What are the students' needs in the Marketing Department at SMK Negeri 1 Kolaka in learning English?" This research uses a qualitative research design where the data are explained in the description form. The instruments of the research are questionnaires and interview guidelines. The participants of the research are students of the Marketing Department in the second grade in SMK Negeri 1 Kolaka. The result showed the student needs, the first is for the student's necessities who are more likely to learn speaking skills, and also for the material they wanted is online marketing material, which means that they considered their needs in the future when they enter the world of work, another thing that students' needs in their English learning is they need a material that is appropriate to their major so that what they learn in school can be applied when they are working later, while the students' lack is their speaking skill and also vocabulary deficiencies. Where they have no space or place to use their English skills that they have learned and for the desires of students in terms of learning English, students are more likely want to learn English by going outside. And for the learning methods that used by the teacher, students are more likely want to study in pairs or groups with their friends rather than study alone. Besides, students also want the teachers who can become facilitators and guides in the English learning process.
\end{abstract}

Keywords: student's needs, lacks, wants, vocabulary deficiencies

\section{INTRODUCTION}

In vocational school, students are taught English with the clear purpose of enabling them to understand English in their field of study. This is referred to as English for Specific Purpose in English. According to Hutchinson and Waters (1987), ESP is divided into two categories: English for Academic Purposes (EAP) and English for Occupational Purposes (EOP) (EOP). EAP is for students who need English for academic purposes such as English for Medical Studies, Economics, and Agriculture, and so on. Although EOP is designed for learners who need English for work training such as English for Technicians and English for Secretaries, students can use it in the future if they apply for jobs.

The ESP a phenomenon would be easy to find in students' specific field, particularly at vocational schools that educate students to achieve their specific goals for enrolling in the school. Teaching English at vocational school must be directed at reaching what the students' need in their field. In this case concerns on how to provide English in a way that meets the needs of the learners. Basturkmen (2010) stated that ESP is a course which concerns on narrower range of topics of English that the students need to learn. It means that the ESP course emphasizes students's importance in mastering qualifications in their field of study. As a result, 
the ESP course prepares students to engage in real-world experiences related to their subject area.

English teaching learning process in vocational school, especially for the Marketing Department, need analysis a suitable format in order to achieve sufficient effectiveness and performance, as well as to achieve the desired production and outcome. Knowing and learning the needs of the teaching-learning method at schools that meet national education standards, and then using the results as a model to design the effective and efficient English in teaching-learning process, is one way to find the right format.

The research question of this study is "What are the students' needs in Marketing Department At SMK Negeri 1 Kolaka in learning English?"

The objective of this research is to find out the students' need in Marketing Department At SMK Negeri 1 Kolaka in learning English

\section{Theoretical Framework \\ Need Analysis}

According to Dahniar (2015), Need analysis (also known as need assessment) refers to the tasks involved in collecting information that is used to create a program that meets the academic needs of a specific group of students. In another way, Flowerdew (2013) suggested that the first step of ESP course creation is to conduct a needs review to determine the "what" and "how" of a course. This is followed by curriculum design, materials collection, methodology, assessment, and evaluation. Such requirements will be language-related in the case of a language program. A need analysis, in basic terms, is a set of exercises used to gather information about the students' learning needs, desires, and wishes, etc. According of Krause (2003) in Fitriani (2017) stated that the need analysis would be formal and detailed, while the time would be informal, concentrated, and brief. Surveys and questionnaires, test scores, and interviews are all possible tools for performing a need study.

Analyzing the target needs and learning needs were some of the ways to define the students' needs, as Hutchinson and Waters (1987) divided the students' needs as follows:

\section{Target Needs}

Target needs according to Hutchinson and Waters (1987) that, what the learner would do in the goal scenario Target needs is a catch-all phrase that encompasses a variety of critical terms such as necessities, deficits, and desires.

\section{a) Necessities}

Necessity is a form of need dictated by the demands of the target situation, and it is essential for students to understand in order to work efficiently in the target situation.

\section{b) Lacks}

To determine the necessities of the learners lacks, we must first determine what the learners already know. The learners' current proficiency must be matched against the goal proficiency. The learners' deficiencies are the difference between the two.

c) Wants 
Wants refers to what the students want or believe they want. Since the goal only requires an objective sense and the individual learners play no active part, the learner often has an understanding of their own needs.

Hutchinson and Waters (1987) argued that the analysis of target situation needs consisted primarily of asking questions about the target situation and the behaviors of the different participants in the learning process toward that situation. The target situation analysis frameworks were:

1. Why was the language needed?

2. How would the language be used?

3. What would the content areas be?

4. Who would the learner use the language with?

5. Where would the language be used?

6. When would the language be used?

It is clear that answers to the questions had to be obtained from a number of sources, and then agreements had to be reached.

\section{Learning Needs}

According to Nurpahmi (2013) a similar checklist is used for target situation analysis to assess learning needs. A framework for analyzing learning needs are:

1. Why were the learners taking the course?

2. How did the learners learn?

3. What sources were available?

4. Who were the learners?

5. Where would the ESP or general course take place?

6. When would the ESP or general course take place?

\section{Purpose of Need Analysis}

In language teaching, needs analysis may be used for a variety of purposes. According to Richards (2001) in Yilmaz (2004), The goals of the needs study were to determine what language skills a learner needs, to assist in deciding whether the current course meets the needs of students, to collect information about students' specific challenges, to learn about students' attitudes toward language learning and the curriculum, and to provide data to serve as the foundation for updating and assessing the existing program. Like Richards, Graves (2000) also discusses the goals of needs analysis, claiming that the primary goal of a needs analysis is to evaluate the language program's purpose. Needs assessments are used in language teaching programs to identify students' language needs in order to assist in the design and evaluation of current curriculum, explore the gap between what students need to learn and what teachers expect from students, and review the courses and textbooks used in the programs. Brown (2001) emphasizes, the importance of needs analysis "....since sound needs analysis forms a rational basis for all the other components of a systematic language curriculum, examining the aims, procedures and the application of needs assessment would create a sound foundation for further discussion of the curriculum".

Richterich and Chancerel (1980) in Yilmaz (2004) argue that since needs analysis is a continuous method, it may be appropriate to perform a needs analysis during and after the course. This could be required to ensure that the program is running in a way that achieves the set goals and objectives. 


\section{Vacational School}

Vocational school is a school which delivers vocational education. The American Heritage Dictionary of the English language (2019) defines it as "a school, especially one on a secondary level that offers instruction and practical introductory experience in skilled trades such as mechanics, carpentry, plumbing, and construction".

The Indonesian vocational school, (Sekolah Menengah Kejuruan) is one type of formal education institution which deliver vocational training in the secondary level of where further education is pursued after junior high school, there is also Islamic Middle School or another type with the same level, or as a continuation from any learning program certified as junior high school or is Islamic Middle School.

\section{ESP in Vocational School}

Basturkmen (2010) ESP Branches, though some studies have documented vocationally-oriented language learning (hereafter VOLL) or Vocational English (VE) programs, the one field of ESP that remains rarely explored in the ESP literature is English for Vocational Purposes (EVP) or Vocational English (VE). In these studies, Since the actual use of the language occurs in authentic contexts, in which students participate, English language programs were contextualized within the framework of acquiring vocational competencies, and English language skills were regarded as social activities and particular disciplines as dynamic (Platt, 1996). To put it another way, the emphasis is on using the language to learn or understand vocational material. In addition, vocacies (language as a complex social practice) and vocational socialization (inducting learners into the community of their chosen vocations or disciplines) are important components of VOLL.

The wassue of VE or VOLL in the context of English as a second language (ESL) has a history dating back to the 1970s (Gage \& Prince, 1982). Within the framework of VOLL, VE refers to a program-enabling learners to communicate not only in the (future) workplace but also provides a more general competence that integrates vocational, linguistic, and social skills (Egloff in Vogt and Kantelinen, 2013).

English for Vocational Purpose (VP) or Vocational English (VE) is viewed as a program socio-institutionally situated in the secondary education sector; Vocational English is designed for students who have a specific career goal in mind. English Vocational Purpose is the starting point for developing EAP, EPP, or EOP competences as students progressed into higher education programs, depending on their specialization. The ESPs are classified into four categories: academic, professional, vocational, and occupational. English for Vocational (EV) is designed to address the English language needs of students in a wide range of specializations who are preparing for immediate jobs as well as higher education at a college, university, or polytechnic.

\section{METHOD}

The researchers used descriptive qualitative method. Descriptive qualitative use in this research because the data obtained by researchers based on qualitative data, then researchers explained the result of the data into descriptive form. The descriptive design is appropriate with this research because it describes what the student need in English and what what the material that is appropriate with them. This research uses two kinds of data collections technique to obtain the data. The techniques are questionare and interview. 


\section{Respondents}

This research was conducted at SMK Negeri 1 Kolaka that is located in Southeast Sulawesi Regency, Indonesia. The questionnaires were distributed to the Second grade of the Marketing Department on the 27th of February. The total of the respondents were 23 students. The total number of students who filled out the questionnaire, there were 11 females and 12 males, for their mean age of $16-18$ years old. The types of data obtained from the questionnaires were quantitative.

\section{Instruments}

The instrument of research determines the validity of the research result. In qualitative research, the researchers were the instrument or it can be named as a human instrument (Sugiyono, 2014). In this research, the researchers check questionnaire guidance and interview

\section{Questionare}

The questionnaire is meant to find out the student's responses toward the suggested technique. In this research, the researchers used close questionnaire. The questionnaire consisted of some questions related to the student's target need. The questions were divided into some parts based on which part of it, such as necessities, lacks, and want. Universal problems were also included in the questionnaires. After the questionnaires were analysed, the researchers sorted the questionnaires of the students in order to interview them regarding they needs in learning English based on their answers on the questionnaires.

To describe what kind of questions in the questionnaires, the researchers made a questionnaire guideline as follows.

Table 1. Guideline of Questionare

\begin{tabular}{|c|c|c|c|}
\hline Aspect & The purpose of question & $\begin{array}{l}\text { Questionare } \\
\text { number }\end{array}$ & Source \\
\hline Necessities & $\begin{array}{l}\text { To find out the needs of by } \\
\text { the demans of target situation }\end{array}$ & $1,2,3,4,5,6,7,8,9,10,11$ & \multirow{3}{*}{$\begin{array}{c}\text { Hutchinson } \\
\text { and Waters } \\
\text { (1987), } \\
\text { Ahmed and } \\
\text { Munir } \\
\text { (2012) }\end{array}$} \\
\hline Lack & $\begin{array}{l}\text { To find out the student lack in } \\
\text { learning English. }\end{array}$ & 12,13 & \\
\hline Want & $\begin{array}{l}\text { To find out the student want } \\
\text { in learning English. }\end{array}$ & $14,15,16,17,18,19,20,21$ & \\
\hline
\end{tabular}

\section{Interview}

There were 5 students who were interviewed in different days. The researchers chose 5 students as respondents to be interviewed based on their academic scores in the previous semester, where 2 students had good grades, 2 students had poor grades and 1 student who had standard scores. From the five students, they can represent all students in the class

To support the validity of data collection, the interview is administered to the students. In this research, the researchers use the semi-structured interview. Arikunto (2010) stated that a semi-structured interview formulates the question but the interviewer may modify the format or questions during the interview process.

The interview is simultaneously carried out with audiotaping. Taking audiotape while interviewing the participants have several benefits. First, the researchers were free to think creatively while the researchers analyze interviewees' statements by comparing them with previous or following statements and with the 
interviews given to others as well. Furthermore, recording the interview session ensured the reliability of the data as the whole data were recorded. Audiotaping the participants' interview mate the researchers more assured that they captured the true essence of interviewees' intents. Meanwhile, the interview consists of 12 questions which were specifically organized based on the following guideline.

Table 2. Guideline of interview

\begin{tabular}{|c|c|c|c|}
\hline No. & Aspect & Item Number & Reference \\
\hline 1 & $\begin{array}{l}\text { Identifying deeply about students' } \\
\text { necessity }\end{array}$ & $\begin{array}{l}1,2,3,4,5,6,7,8,9,10,11, \\
12,13,14,15\end{array}$ & \multirow{3}{*}{$\begin{array}{c}\text { Hutchinson } \\
\text { and Waters } \\
\text { (1987), } \\
\text { Ahmed and } \\
\text { Munir } \\
\text { (2012) }\end{array}$} \\
\hline 2 & $\begin{array}{l}\text { Identifying deeply about students' } \\
\text { lack }\end{array}$ & $16,17,18,19,20$ & \\
\hline 3 & $\begin{array}{l}\text { Identifying deeply about students' } \\
\text { want }\end{array}$ & $\begin{array}{l}21,22,23,24,2526,27,28,29,30 \\
31,32\end{array}$ & \\
\hline
\end{tabular}

\section{Procedures of the research}

This section discusses about the procedure of the research from the start until the end. The procedure were taken from Tayie (2005) and modified as needed to be used in this research.

The researchers decided to use triangulation method on collecting data in this research. Triangulation meant using more than one method to collect data on the same topic. However, the purpose of triangulation is not necessarily to crossvalidate data but rather to capture different dimensions of the same phenomenon. The interview conducted after the questionnaires collect from the students, but first it is sorted and chosen based on some criterions, such as the relevance of it with this research, quality of the data, etc. The data acquired from this is qualitative data

The researchers found that there was reoccurring phenomenon that happens everywhere relate to English learning. The researchers were interested to find out what students' target need. After that the researchers started collecting data regarding to the topic in this step. There were various data acquired from different sources that helped in developing the theories as well as to back up the researchers's opinion on what students' target need. These factors collected, and narrowed down to make the research less broad. The researchers then divided the students'target need into three parts; neseccities lacks and wants.

After determining the topic and research questions, as well as reviewing previous theories, the researchers decided to use descriptive qualitative method in order to answer the research questions. It is chosen because the researchers considered that it is the best method to describe such phenomenon.

\section{Data collection}

The data is obtained through questionnaire and interview of the students. The questionnaire consists of some questions related to the topics. The type of the questionnaire mix between open and close ended questions depends on what data the researchers wanted to acquire. The data collection did in two phases. First, the questionnaire was distributed to the students and given time to answer. After the questionnaire data obtained, it was then sorted based on the need of the researchers. The second, participants chose to be interviewed based on their answers on the questionnaires and the relevance of the research. After that, the researchers analyzed the data that were obtained previously. The data processed and put on the 
list based on what studen need most. After the data analyzed, the researchers drew conclusion regarding the topic.

\section{Data analysis}

The questionnaire data collection, sort and reduction based on the relevance with this research. In other words, only the questionnaire of the students who are negatively affect take into account. Meanwhile, the questionnaires of students who have no difficulties are not included in the research. To analyze the data obtained through the questionnaire, the researchers use Central Tendency Measures which consisted of mean, median and mode. It used to determine the central point of the scores distribution of the data and variability (standard deviation) to measure whether the data is homogenous or not (Hatch and Farhady, 1982 in Isfahani, 2014). Ideal mean (Mi) and ideal standard deviation (SDi) are also used to converse the data (Sudjiono, 2003 in Fatmasari, 2013). The formula of both ideal mean and ideal standard of this research are:

1. $\mathrm{Mi}=1 / 2($ Maximum score + Minimum score $)$

$$
\begin{aligned}
& =1 / 2 \quad(4+1) \\
& =2,5
\end{aligned}
$$

2. $\mathrm{SDi}=1 / 6$ (Maximum score - minimum score)

$$
=1 / 6(4-1)
$$

$$
=0.5
$$

After being calculated, the data were categorized into five grades: very affecting, affecting, not affecting, and very not affecting. This categorization is based on Sudijono's quantitative data conversion as shown in the following table.

Table 3. Quantitative Data Conversion Adapted from Sudijono (2003)

\begin{tabular}{|c|c|c|c|}
\hline No. & Score Range Formula & Score Range & Category \\
\hline 1. & $\bar{X}>M i+1.5 S D i$ & $\bar{X}>3.25$ & Very Agree \\
\hline $\mathbf{2}$ & $M i+0.5 S D i<\bar{X} \leq M i+1.5 S D i$ & $2.75<\bar{X} \leq 3.25$ & Agree \\
\hline $\mathbf{3}$ & $M i-0.5 S D i<\bar{X} \leq M i+0.5 S D i$ & $2.25<\bar{X} \leq 2.75$ & Fairly Agree \\
\hline $\mathbf{4}$ & $M i-1.5 S D i<\bar{X} \leq M i-0.5 S D i$ & $1.75<\bar{X} \leq 2.25$ & Disagree \\
\hline $\mathbf{5}$ & $\bar{X} \leq M i-1.5 S D i$ & $\bar{X} \leq 1.75$ & Very Disagree \\
\hline
\end{tabular}

Where :

$\bar{X} \quad=$ the average mean

$\mathrm{Mi}=$ the ideal mean

SDi = the standar Deviation

\section{RESULTS AND DISCUSSION}

\section{Results}

Presents the results of the research about the results of students' questionnaires and interviews analysis

\section{The Result of the Students' Questionnaires and Interviews}

Below is the data found by the researchers regarding the students' needs in learning English. This section devided into three parts, such as: students neccesities, students lacks and students wants 


\section{a) The Result of Students' Necessities}

Below is the result of the questioners regarding the students' necessities in learning English.

\section{Why did you need to learning English?}

\begin{tabular}{|l|c|c|c|}
\hline Statement (Pernyataan) & N & Mean & Category \\
\hline Higher education & 23 & 2.8 & Agree \\
\hline Success fo future profession & 23 & 3.5 & Very Agree \\
\hline Speak to foreigners & 23 & 2.9 & Agree \\
\hline Speak to friend and family & 23 & 2 & Disagree \\
\hline Total & 23 & 2.8 & Agree \\
\hline
\end{tabular}

The result of the analysis showed that the higher mean value of the first question is 3.5 or most of them very agree that is a success for the future profession which mean that it is the factor that made student need to learn English and the lower mean value is speak to friend and family. (Appendix/Interview Transcript/A/D.10)

\section{When did you use English?}

\begin{tabular}{|c|c|c|c|}
\hline Statement (Pernyataan) & $\mathbf{N}$ & Mean & Category \\
\hline I use English when I have English class & 23 & 3.4 & Very Agree \\
\hline $\begin{array}{l}\text { I use English when I am studying any } \\
\text { English references related to my major }\end{array}$ & 23 & 3.1 & Agree \\
\hline $\begin{array}{l}\text { I use English when I am socializing } \\
\text { with my friends or my relatives }\end{array}$ & 23 & 2.26 & Agree \\
\hline I use English when I am at home & 23 & 2.1 & Disagree \\
\hline $\begin{array}{c}\text { Total } \\
\end{array}$ & 23 & 2.71 & Agree \\
\hline
\end{tabular}

The result of the analysis showed that the higher mean value of the second question is 3.4 or most of the students very agree that is they use English when they having English class which mean that it is the moment they used English because the mean value is more than 3.25 and the lower mean value is they use English at home. (Appendix/Interview Transcript/MA/C.12)

\section{In the future, I would use English for?}

\begin{tabular}{|l|c|c|c|}
\hline \multicolumn{1}{|c|}{ Statement (Pernyataan) } & N & Mean & Category \\
\hline My next study & 23 & 3 & Agree \\
\hline My future career & 23 & 3.28 & Very Agree \\
\hline My social life & 23 & 2.56 & fairlyAgree \\
\hline My inner family life & 23 & 2 & Disagree \\
\hline Total & 23 & 2.71 & Agree \\
\hline
\end{tabular}

The result of the analysis showed that the higher mean value of the third question is 3.28 or most of the students that were they would use English for their future career and the lower mean is they would use English for their inner life. (Appendix/Interview Transcript/A/D.14) 


\section{What skills did you like to be more emphasized in the Marketing area?}

\begin{tabular}{|c|c|c|c|}
\hline Statement & N & Mean & Category \\
\hline Listening & 23 & 3 & Agree \\
\hline Speaking & 23 & 3.3 & Very Agree \\
\hline Reading & 23 & 2.95 & Agree \\
\hline Writing & 23 & 3 & Agree \\
\hline Vocabulary & 23 & 2.13 & Disagree \\
\hline Grammar & 23 & 2.56 & Fairly Agree \\
\hline Total & 23 & 2.82 & Agree \\
\hline
\end{tabular}

The result of the analysis showed that the higher mean value of the fourth question is 3.3 or most of the students very agree that is speaking skill is more emphasized in the marketing area and then listening and writing. (Appendix/Interview Transcript/H/B.16)

\section{What the topic of your major that you want to emphasized in Marketing area?}

\begin{tabular}{|l|c|c|c|}
\hline \multicolumn{1}{|c|}{ Statement } & N & Mean & Category \\
\hline Marketing basic & 23 & 2.6 & Fairly Agree \\
\hline Product & 23 & 2.5 & Fairly Agree \\
\hline Product arrangement & 23 & 3 & Agree \\
\hline People-Costumer and staff & 23 & 2.4 & Fairly Agree \\
\hline Place & 23 & 2.98 & Agree \\
\hline Packaging & 23 & 2.76 & Agree \\
\hline Public Relation & 23 & 2.45 & Fairly Agree \\
\hline Price & 23 & 2.2 & Disagree \\
\hline Creative product and intrepeneurial & 23 & 3 & Agree \\
\hline Retail business management & 23 & 2.9 & Agree \\
\hline Online marketing & 23 & 3.45 & VeryAgree \\
\hline Transaction administration & 23 & 3 & Agree \\
\hline Total & 23 & 2.77 & Agree \\
\hline
\end{tabular}

The result of the analysis showed that the higher mean value of the fifth question is 3.45 or most of the students very agree that is online marketing topic that is more interesting than others to become the topic that emphasized in the marketing area. (Appendix/Interview Transcript/H/B.18)

\section{How often did you use English in studying your major courses?}

\begin{tabular}{|l|c|c|c|}
\hline \multicolumn{1}{|c|}{ Statement } & N & Mean & Category \\
\hline Ask questions in English & 23 & 2.5 & Sometimes \\
\hline Discuss materials in English & 23 & 2.44 & Sometimes \\
\hline Give a speech in English & 23 & 1.75 & Rarely \\
\hline Present oral reports in English & 23 & 2 & Rarely \\
\hline Read English reference books & 23 & 2.5 & Sometimes \\
\hline Read English textbooks & 23 & 2.88 & Often \\
\hline Read English journals & 23 & 2.37 & Sometimes \\
\hline Read English texts from Internet & 23 & 2.59 & Sometimes \\
\hline Answer tests \& exams in English & 23 & 3.27 & Always \\
\hline Write class notes in English & 23 & 2.67 & Sometimes \\
\hline
\end{tabular}




\begin{tabular}{|c|c|c|c|}
\hline Write English reports/assignments & 23 & 1.8 & Rarely \\
\hline Total & 23 & 2.67 & Sometimes \\
\hline
\end{tabular}

The result of the analysis showed that the higher mean value of the Sixth question is 3.27 or most of the students very agree that is answer tests \& exams in English that they always used the English language in learning English on their major. (Appendix/Interview Transcript/A/D.19)

7. Which of the following English listening comprehension sub skills did you think is more important than the others for your study of your major courses?

\begin{tabular}{|l|c|c|c|}
\hline \multicolumn{1}{|c|}{ Statement } & N & Mean & Category \\
\hline $\begin{array}{l}\text { Understand questions asked by other } \\
\text { fellow students }\end{array}$ & 23 & 2.44 & Fairly Agree \\
\hline Understand teacher in order to take notes & 23 & 2.8 & Agree \\
\hline Understand classroom discussion & 23 & 3 & Agree \\
\hline Understanding client presentation & 23 & 3.51 & Very Agree \\
\hline Total & 23 & 2.93 & Agree \\
\hline
\end{tabular}

The result of the analysis showed that the higher mean value of the Seventh question is 3.51 or most of the students very agree that is understanding client presentation would more emphasized in listening sub-skill at the marketing department.

(Appendix/Interview Transcript/A/D.22)

8. Which of the following English speaking sub skills did you think is more important than the others for your study of your major courses?

\begin{tabular}{|l|c|c|c|}
\hline \multicolumn{1}{|c|}{ Statement } & N & Mean & Category \\
\hline Ask questions in the classroom & 23 & 1.97 & Disgree \\
\hline Discuss the materials of the teacher & 23 & 2 & Disagree \\
\hline Give a speech & 23 & 2.4 & Fairly Agree \\
\hline Present oral classroom reports & 23 & 2.68 & Fairly Agree \\
\hline Making appointment by phone & 23 & 3.44 & Very Agree \\
\hline Asking for information on a company & 23 & 3.1 & Agree \\
\hline Organizing Presentation & 23 & 2.77 & Agree \\
\hline Organizing meeting with client & 23 & 3 & Aagree \\
\hline Total & 23 & 2.67 & Fairly Agree \\
\hline
\end{tabular}

The result of the analysis showed that the higher mean value of the eighth question is 3.44 or the student very agree that is making an appointment in speaking sub-skill that more important for students to learn in the marketing department. (Appendix/Interview Transcript/MKI/A.24)

9. Which of the following English reading comprehension sub skills did you think is more important than the others for your study of your major courses?

\begin{tabular}{|l|c|c|c|}
\hline \multicolumn{1}{|c|}{ Statement } & N & Mean & Category \\
\hline Reading texts from internet & 23 & 2.1 & Disagree \\
\hline Reading textbooks & 23 & 2.74 & Agree \\
\hline Reading reference books & 23 & 1.88 & Disgree \\
\hline
\end{tabular}


Journal of English Teaching Adi Buana, Vol. 06 No. 01, April 2021

\begin{tabular}{|c|c|c|c|}
\hline Reading professional journals & 23 & 2.2 & Disgree \\
\hline Reading to understand test and exam question & 23 & 3 & Agree \\
\hline Reading dialog & 23 & 2.87 & Agree \\
\hline Reading newspaper & 23 & 3.1 & Agree \\
\hline Reading marketing strategis & 23 & 3.27 & Very Agree \\
\hline Reading advertising & 23 & 3 & Agree \\
\hline Total & 23 & 2.68 & Agree \\
\hline
\end{tabular}

The result of the analysis showed that the higher mean value of the ninth question is 3.27 or most of the students very agree, that is reading marketing strategies in reading subskill that more important for students to learn in the marketing department. (Appendix/Interview Transcript/H/B.26)

10. Which of the following English writing sub skills did you think is more important than the others for your study of your major courses?

\begin{tabular}{|l|c|c|c|}
\hline \multicolumn{1}{|c|}{ Statement } & N & Mean & Category \\
\hline Writing correct sentences & 23 & 3.65 & Very Agree \\
\hline Writing class notes & 23 & 2.91 & Agree \\
\hline Writing test and exam answers & 23 & 2.82 & Agree \\
\hline Writing reports & 23 & 2.78 & Agree \\
\hline Writing bussines letter & 23 & 3 & Agree \\
\hline Writing memorandum & 23 & 2.34 & Fairly Agree \\
\hline Writing appplication letter & 23 & 2.33 & Fairly Agree \\
\hline Writing a resume & 23 & 2.26 & Fairly Agree \\
\hline Writing CV Total & 23 & 2.34 & Fairly Agree \\
\hline \multicolumn{2}{|c|}{ Tole } \\
\hline
\end{tabular}

The result of the analysis showed that the higher mean value of the tenth question is 3.65 , that is writing a correct sentence in speaking sub-skill that more important for students to learn in the marketing department. (Appendix/Interview Transcript/A/D.28)

\section{What percentage of English materials in the English language course should be relevant to your field of specialization?}

\begin{tabular}{|c|c|c|c|}
\hline Statement & N & Mean & Category \\
\hline $90-100 \%$ & 23 & 3.08 & Agree \\
\hline $70-89 \%$ & 23 & 2.65 & Fairly Agree \\
\hline $50-69 \%$ & 23 & 2.52 & Fairly Agree \\
\hline $30-49 \%$ & 23 & 2.21 & Fairly Agree \\
\hline Less than (kurang dari) $30 \%$ & 23 & 2 & Disagree \\
\hline Total & 23 & 2.75 & Agree \\
\hline
\end{tabular}

The result of the analysis showed that the higher mean value of the eleventh question is 3.08, that is the student who agrees if the percentage of English materials in the English language course should be relevant to your field of specialization around $90-100 \%$. (Appendix/Interview Transcript/MKI/A.30)

\section{b) The Result of Students' Lacks}

Below is the result of the questioners regarding the students' lack in learning English. 
12. What is you present proficiency in academic English language skills ?

\begin{tabular}{|l|c|c|c|}
\hline \multicolumn{1}{|c|}{ Statement } & N & Mean & Category \\
\hline Listening (mendengarkan) & 23 & 2 & Bad \\
\hline Speaking (berbicara) & 23 & 1.74 & Very Bad \\
\hline Reading (membaca) & 23 & 2.26 & Average \\
\hline Writing (menulis) & 23 & 1.76 & Bad \\
\hline Total & 23 & 2.44 & Average \\
\hline
\end{tabular}

The result of the analysis showed that the higher mean value of the twelfth question is 2.26 , that is reading skill better than other skill, and almost all of the skill have problem with a student, the table show speaking skill become a skill that very bad category about student proficiency. (Appendix/Interview Transcript/A/D.32)

\section{What is your problem in learning English?}

\begin{tabular}{|l|c|c|c|}
\hline \multicolumn{1}{|c|}{ Statement } & N & Mean & Category \\
\hline Limited vocabulary & 23 & 3.30 & Very Agree \\
\hline Poor grammar & 23 & 2.71 & Fairly Agree \\
\hline Poor listening comprehention skill & 23 & 2.90 & Agree \\
\hline Poor speaking skill & 23 & 3.26 & Very Agree \\
\hline Poor reading comprehention skill & 23 & 2 & Disagree \\
\hline Poor writing skill & 23 & 2.26 & Fairly Agree \\
\hline \multicolumn{1}{|c|}{ Total } & 23 & 2.76 & Agree \\
\hline
\end{tabular}

The result of the analysis showed that the higher mean value of the thirteenth question is 3.30 and 3.26, that is limited vocabulary and poor speaking skills become a problem in learning English for students in the marketing department. (Appendix/Interview Transcript/MKI/A.34)

\section{c) The Result of Srudents' Want}

Below is the result of the questioners regarding the students' want in learning English.

\section{What the activities that you like in learning English?}

\begin{tabular}{|l|c|c|c|}
\hline \multicolumn{1}{|c|}{ Statement } & N & Mean & Category \\
\hline Student presentation & 23 & 3 & Agree \\
\hline Project & 23 & 2.66 & Fairly Agree \\
\hline Quiz & 23 & 2.79 & Agree \\
\hline Discussion & 23 & 3.55 & Very Agree \\
\hline Outdoor class Total & 23 & 3.6 & Very Agree \\
\hline \multicolumn{2}{|c|}{23} & 3 & Agree \\
\hline
\end{tabular}

The result of the analysis showed that the higher mean value of the fourteenth question is 3.6 and 3.55 or most of the students very agree that is a discussion and the outdoor class becomes the activities that students like in the marketing department. (Appendix/Interview Transcript/H/D.36) 
15. What is the method in learning English that you like in Marketing area?

\begin{tabular}{|l|c|c|c|}
\hline \multicolumn{1}{|c|}{ Statement } & N & Mean & Category \\
\hline Alone & 23 & 2.39 & Fairly Agree \\
\hline Work in pairs & 23 & 3.30 & Very Agree \\
\hline Small group & 23 & 3 & Agree \\
\hline Big group & 23 & 3.27 & Very Agree \\
\hline Learning form text while make a note & 23 & 2.95 & Agree \\
\hline Role play Total & 23 & 2.47 & Fairly Agree \\
\hline \multicolumn{2}{|c|}{23} & 2.90 & Agree \\
\hline
\end{tabular}

The result of the analysis showed that the higher mean value of the fifteenth question is 3.30 and 3.27, that is work in pairs and the big group becomes the method that students alike in learning English in the marketing department. (Appendix/Interview Transcript/MA/C.38)

\section{What kind of role did you like your teacher to have?}

\begin{tabular}{|l|c|c|c|}
\hline \multicolumn{1}{|c|}{ Statement } & N & Mean & Category \\
\hline $\begin{array}{l}\text { Preference for the role of teacher as a } \\
\text { facilitator and guide }\end{array}$ & 23 & 3.47 & Very Agree \\
\hline $\begin{array}{l}\text { Preference for traditional role of teacher as } \\
\text { someone in control of everything in class }\end{array}$ & 23 & 3.2 & Agree \\
\hline Total & 23 & 3.22 & Agree \\
\hline
\end{tabular}

The result of the analysis showed that the higher mean value of the sixteenth question is 3.47 or most of the students very agree that is student very agree if a preference for the role of a teacher as a facilitator and guide in the marketing department. (Appendix/Interview Transcript/A/D.40)

\section{What is main English Language Skills tht you Desire to Learn?}

\begin{tabular}{|l|c|c|c|}
\hline \multicolumn{1}{|c|}{ Statement } & N & Mean & Category \\
\hline Listening (mendengarkam) & 23 & 3 & Agree \\
\hline Speaking (berbicara) & 23 & 3.45 & Very Agree \\
\hline Reading (membaca) & 23 & 2.73 & Fairly Agree \\
\hline Writing (menulis) & 23 & 2.81 & VeryAgree \\
\hline Total & 23 & 2.9 & Agree \\
\hline
\end{tabular}

The result of the analysis showed that the higher mean value of the seventeenth question is 3.45 or most of the students very agree that is speaking skill is the skill that students desire to learn in the marketing department. (Appendix/Interview Transcript/H/B.42)

18. What is English listening comprehension sub-skills that you desire to learn?

\begin{tabular}{|l|c|c|c|}
\hline \multicolumn{1}{|c|}{ Statement } & N & Mean & Category \\
\hline $\begin{array}{l}\text { Understanding questions asked by other } \\
\text { fellow students }\end{array}$ & 23 & 2.11 & Disagree \\
\hline Understanding lectures in order to take notes & 23 & 1.90 & Disagree \\
\hline Understanding classroom discussion & 23 & 2.89 & Agree \\
\hline Understanding client presentation & 23 & 3.55 & Very Agree \\
\hline
\end{tabular}




\begin{tabular}{l|l|l|l} 
Total & 23 & 2.90 & Fairly Agree \\
\hline
\end{tabular}

The result of the analysis showed that the higher mean value of the eighteenth question is 3.55 , that is understanding the client presentation that the listening comprehension sub-skill that students desire to learn in the marketing department. (Appendix/Interview Transcript/MKI/A.44)

\section{What is English speaking sub-skills that you desire to learn?}

\begin{tabular}{|c|c|c|c|}
\hline Statement & $\mathbf{N}$ & Mean & Category \\
\hline Ask questions in the classroom & 23 & 2.23 & Disgree \\
\hline Discuss the materials of the teacher & 23 & 1.91 & Disagree \\
\hline Give a speech & 23 & 2.34 & Fairly Agree \\
\hline Present oral classroom reports & 23 & 1.90 & Disgree \\
\hline Making appointment by phone & 23 & 3.29 & Very Agree \\
\hline Asking for information on a company & 23 & 3 & Agree \\
\hline Organizing Presentation & 23 & 2.88 & Agree \\
\hline Organizing meeting with client & 23 & 3.11 & Aagree \\
\hline Total & 23 & 2.57 & Fairly Agree \\
\hline
\end{tabular}

The result of the analysis showed that the higher mean value of the nineteenth question is 3.29 , that is making an appointment by phone in speaking sub-skill that desire to learn in the marketing department. (Appendix/Interview Transcript/H/B.46)

\section{What is English reading comprehention sub-skills that you desire to learn?}

\begin{tabular}{|c|c|c|c|}
\hline Statement & $\mathbf{N}$ & Mean & Category \\
\hline Reading texts from internet & 23 & 3 & Agree \\
\hline Reading textbooks & 23 & 2.80 & Agree \\
\hline Reading reference books & 23 & 1.88 & Disagree \\
\hline Reading professional journals & 23 & 2.67 & Fairly Agree \\
\hline Reading to understand test and exam question & 23 & 2 & Disagree \\
\hline Reading dialog & 23 & 2.66 & Fairly Agree \\
\hline Reading newspaper & 23 & 2.90 & Agree \\
\hline Reading marketing strategis & 23 & 3.49 & Very Agree \\
\hline Reading advertising & 23 & 2.1 & Disagree \\
\hline Total & 23 & 2.88 & Agree \\
\hline
\end{tabular}

The result of the analysis showed that the higher mean value of the twentieth question is 3.49 , that is, reading marketing strategies in reading sub-skill that desire to learn in the marketing department. (Appendix/Interview Transcript/A/D.48)

\section{What is English writing sub-skills that you Desire to Learn?}

\begin{tabular}{|l|c|c|c|}
\hline \multicolumn{1}{|c|}{ Statement } & N & Mean & Category \\
\hline Writing correct sentences & 23 & 3.55 & Very Agree \\
\hline Writing class notes & 23 & 3 & Agree \\
\hline Writing test and exam answers & 23 & 2.28 & Fairly Agree \\
\hline
\end{tabular}


Journal of English Teaching Adi Buana, Vol. 06 No. 01, April 2021

\begin{tabular}{|c|c|c|c|}
\hline Writing reports & 23 & 2.79 & Agree \\
\hline Writing bussines letter & 23 & 3 & Agree \\
\hline Writing memorandum & 23 & 2.66 & Fairly Agree \\
\hline Writing appplication letter & 23 & 3.20 & Agree \\
\hline Writing a resume & 23 & 2.54 & Fairly Agree \\
\hline Writing CV & 23 & 2.90 & Agree \\
\hline Total & 23 & 2.90 & Agree \\
\hline
\end{tabular}

The result of the analysis showed that the higher mean value of the tenth question is 3.55 , that is, writing a correct sentence in writing sub-skill that desire to learn in the marketing department.

(Appendix/Interview Transcript/H/B.50)

\section{DISCUSSION}

Based on the findings, it is found that there were some students needed in learning English at the marketing department. To make these findings more relevant and to answer the research question of this research, the researchers only focused to discuss spesific questions in questionare or interviews with the marketing department.

The discussion is divided into 3 sections or aspects based on the student need, i.e. neccessities, lack and want

\section{Discussion of Students' Neccesities}

Based on the result of the questionnaires, the researchers found 11 student necessities that included specific and general. But, to make it efficient the researchers just discussed the specific necessities in the marketing department. The first necessity is speaking skills to be more emphasized. It is skill become the skill that students need in the marketing department. It is proven of mean value in the questionnaire at 3.3. One of student admitted that in the marketing department more about presentations such as presenting a product directly that made speaking skills very important. This proves the statement of Nunan (2000), Speaking is very important in our life because without speaking we did not know what the other talk and speaking also is the way that we used to interact with the other people.

The second necessity is online marketing topics more emphasized to learn. Online marketing is one of the topics in the marketing department that students want to learn in English. It is proven of mean value in the questionnaire at 3.45. one of student said now the role of social media in marketing is very influential, it could be seen from so many people use social media to develop their business. In their mind, by studying online marketing using English, business opportunities not only domestically but also abroad. This inline with the statement of eMarketer (2019) Worldwide business-to-consumer e-commerce sales increased by $20.1 \%$ in 2019 reaching $\$ 1500$ trillion. There is an expansion of online and mobile users across the globe, especially from emerging markets, e-commerce sales were constantly rising, 
shipping and payment options have been simplified and major global brands have been pushed into new international markets (www.eMarketer.com, 2019).

The third necessity is understanding client presentation more emphasized to be learned in the listening sub-skill. In understanding client presentation, students can get the point of the presentation. It is indicated by the mean value in the questionnaire at 3.45 based on the student interviewed, one of the students said the presentation is an important part of marketing because in the presentation there were important points of a product that must be understood by the listener. This proves the statement of Waringin (2008), Presentation is intended for explaining and demonstrate products or services, communication messages can be varied according to prospective buyers, communication can be directed to candidate special customer, the cost can be controlled by adjusting the amount sales force, and very effective in generating sales as well grow buyer satisfaction.

The fourth necessity is making an appointment by phone more emphasized to be learned in speaking sub-skill. In speaking skills, making an appointment by telephone is one of the parts students must study in the marketing department. It is proven of mean value in the questionnaire at 3.44 based on students interviewed. The student said learning how to make agreements correctly is very important to learn especially in marketing majors. Because of that way, they knew better how to made agreements with business partners appropriately.

The fifth necessity is marketing strategies more emphasized to be learned in speaking sub-skill. Information is easily accessed by anyone, including students. Understanding marketing strategies is very important to made sales run smoothly and well planned. Marketing strategy not only exists from within the country but also from abroad. Which, the overseas strategy is very much recommended for students to learn it also to add references which of course most-used English. It is proven of mean value in the questionnaire at 3.27. one of the students said in marketing there were certainly strategies that must be used, and good strategies not only from within the country but also from abroad, which is where we can learn their marketing strategies so that their market runs smoothly.

The sixth necessity is writing correct sentences more emphasized to be learned in writing sub-skill. The writing is the most important part in conveying a message or intent and purpose in writing, in conveying a message. The writer must blindly sentence properly so that the written message can be conveyed properly. In marketing, the writing is a means for students to write letters or curriculum vitae and others that they can later use that relate to their work later and of course just used the correct sentence. It is proven of mean value in the questionnaire at 3.65 one of student said marketing is not always about talking, but there were times when you have to write, for example writing letters. In making a letter, of course, it just used the right tenses and the appropriate sentence so that the purpose we wanted to convey through an article can be understood. This in line with the statement of Suadnyani (2009), writing a correct sentence is important because writing can be a means to found something, come up with ideas new, training ability organize and clear up various concepts or ideas, practice attitudes the objective that is in someone, helps to absorb and process information, and train to think actively. Thus, it is clear that writing very useful, despite being behind it writing process seems still difficult. 
The seventh necessity is the percentage of English material should be relevant to marketing around $90 \%-100 \%$. The material is the most important part of learning is no exception to the marketing department. With learning under the needs of students it can be made learning more effective. It is proof of the mean value in the questionnaire at 3.08 one of student admitted the appropriate material with the majors, can be made easier when already working because most of what we do has been learned at school so that what has been learned is not in vain. It can be said that learning is done with adjusting to the needs of students and focusing on students as the main consideration in learning.

\section{Discussion of Students' Lacks}

Based on the result of the questionnaires, the researcherss found 3 students were lack in.speaking, limited vocabulary \& poor speaking skills. The first lack is speaking. the speaking skill is one of the problems faced by students in the marketing department, and it contrasted with the needs of students in marketing majors such as speaking. It is proven of mean value in the questionnaire at 1.74 or very bad. one student admitted one of the student's lack is poor speaking skills because at school it is very rare to do practice and they are ashamed to speak because there is no place to do it and also still fewer students used English and even students used it. This proved the statement of Tarigan (2011) stated that speaking skills were a mechanistic skill. The more you practice speaking, the more mastered the speaking skills.

The second lack is limited vocabulary. besides having deficiencies in speaking, students also did not have a lot of vocabulary which were both interrelated, if lack of vocabulary will certainly prevent students from speaking. It is proven of mean value in the questionnaire at 3.30 or very agree. The student said to arrange words into sentences of course we have to knew a lot of vocabulary. They didn't learn a lot of vocabulary which made them lack vocabulary. Rebecca (2010) said that understanding vocabulary is an important component of speaking, either speak in one's own language as well as speak in a foreign language.

\section{Discussion of Students' Wants}

Based on the result of the questionnaires, the researchers found 8 students want. The first want is activities in outdoor class and discussion. Learning outside the room can make students more enthusiastic in learning because it has a comfortable atmosphere for students to think. It is proof of the mean value in the questionnaire at 3.6 for outdoor class and 3.55 for discussion. Students said by learning outside made us free to express even more the cool atmosphere made us more enthusiastic in learning and besides that, other activities like discussion made us more active because we can exchange opinions. The place of study becomes one factor of student learning. The outdoor class is one of the effective places for students to learn English.

The second want is method in learning English is to work in pairs. working in pairs can be made students more quickly understand because they can be discussed with their friends and made the learning process more effective. It is proven of mean value in the questionnaire at 3.30 or very agree. Students said learning in groups or pairs is very helpful for us in learning English because we can unite our opinions with each other and also we were more able to learn together 
with smarter students to improve our ability to learn English. Scrivener (2012), pair work refers to a kind of classroom interaction that involves one student working with another student to do a communicative activity, giving feedback, and discussing an issue.

The third want is the preference for the role of the teacher as a facilitator and guide. the teacher is one of the important factors in the teaching and learning process, the teacher must be able to become a facilitator and guide students to understand with the material that encourages. It is proven of mean value in the questionnaire at 3.47 or very agree. one student admitted the teacher as a facilitator gives a good impact on students. where students can ask questions when they were not understood and can be guided to understand the material. This proved the statement of Condruta (2012) he said that facilitators should be allowed students to determine their learning needs and objectives and made used of various resources. They conducted discussions and grease the wheels for real-world examples and achieve this through a considerable system of techniques and methods.

The fourth want is skill in English they desire to learn is speaking. Speaking skill is so important in marketing majors. so that not only as a need and also students want to master these skills. It is proven of mean value in the questionnaire at 3.45 or very agree. The student said the ability to speak is very important because when we want to market a product and also collaborate with people abroad, of course must be able communicated in English. For those of us working to succeed in business, we have no choice but to embrace the need for public speaking and presenting skills (claymorganonline.com, 2018).

The fifth want is understanding client presentation is the desire to be learned in listening sub-skill. knowing the contents of presentations from business partners is very important because that way we can provide feedback or suggestions that can help or develop our business. It is proven of mean value in the questionnaire at 3.55 or very agree. The student said in interviewed understanding the contents of the client's presentation is very important because when our clients deliver the contents or substances contained in the product we can understand. According to Purwanto (2011), business presentations have many purposes for visits to discuss business messages to the audience.

The sixth want is making an appointment by phone is the desire to be learned in speaking sub-skill. making agreements with clients is one of the things that must be studied in the marketing department. It is proven of mean value in the questionnaire at 3.55 or very agree. Students said students in marketing majors need to know how to make agreements via telephone correctly, when later they want to agree with a business partner it will not be difficult.

The seventh want is reading marketing strategies is a desire to be learned in speaking sub-skill. Knowing the marketing strategy is an important thing for students majoring in marketing, especially strategies that come from abroad who of course had a good strategy for the development of a business. It is proven of mean value in the questionnaire at 3.49 or very agree. one of student admitted knowing the marketing strategy can broaden the horizons of a good strategy in marketing moreover the strategy comes from abroad which of course has a good strategy which is where the strategy generally uses English. According to Isnaini (2010), having high-quality products is not even enough to dabble in the world of entrepreneurship, but had a good marketing strategy can determine the success of a 
business. from this explanation that the marking strategy must be learned not only from within the country but also from abroad.

The eighth want is writing correct sentences is desire to be learned in writing sub-skill. Writing the correct sentence is very desirable for students to learn, especially in marketing majors, although they tend to speak more but have the right writing skills need to know. It is proven of mean value in the questionnaire at 3.55 or very agree. one of the students admitted writing the correct sentence is very important for us to learn, for example when we want to send letters to business partners who come from abroad, of course, we have to use English and write correct sentences because our writing is wrong then the possibility of the meaning we want to convey will be hampered. Cahyani \& Rosmana, (2013) argued that writing is lowering or depicting graphic symbols that describe a language that someone understands so that other people can read the symbols of the graph.

\section{CONCLUSION}

Based on the results of the questionnaires and interview, the researchers conclude that there are student's needs in learning English at Marketing Department of SMK Negeri 1 Kolaka. The first is for the students necessities who are more prefer to learn speaking skills, and also for the material they want is online marketing material, which means that they consider their needs in the future when they enter the world of work, another thing that students need is in their English learning is they need material that is appropriate to their major so that what they learn in school can be applied when they are working later, while the students lack is more likely to lead to their speaking skills and also vocabulary deficiencies. Where they have no space or place to use their English skills of what they have learned. And for the desires of students in terms of learning English, students are more likely want to learn English outside of classroom and also for the learning methods used by the teacher, students were more likely to study in pairs or groups with their friends rather than study alone. In addition, students also want their teachers to become facilitator and guide in the English learning activity.

\section{REFERENCES:}

Arikunto, S. (2010). Prosedur Penelitian, Yogyakarta: PT. Rineka Cipta.

Basturkmen, Helen. (2010). Developing Course in English for Specific Purposes, New York: Palgrave Macmillan.

Black. (2010). Business Statistic: Contemporary decision making, 6th Edition. John Wouldey and Sons,.

Brown, J. D. (2001). The Elements of Language Curriculum. Boston: Heinle \& Heinle.

Cahyani, I \& Rosmana, A. (2006). Pendidikan Bahasa Inggris . Bandung: UPI PRESS

Claymorganonline.com (2018), Why Are Speaking Skills Important For Business Success?, https://claymorganonline.com/speaking-skills-business-success/ accessed on $11^{\text {th }}$ August 2020.

Condruta, B.E. (2012). Teacher as Learning Facilitator in ELT. European integration-Realities and Perspektives 
Dahniar. (2015). Developing Task-Based Syllabus Based on Needs Analysis for Midwifery at UIN Alauddin Makassar. Makassar: Graduate Program, State University of Makassar,.

eMarketer: Global B2C Ecommerce Sales to Hit \$1.5 Trillion This Year Driven by Growth in Emerging Markets - 2019. https://www.emarketer.com/Article/Global-B2C-Ecommerce-Sales-Hit-15Trillion-This-YearDriven-by-Growth-Emerging-Markets/1010575, accessed at $2^{\text {nd }}$ July 2020.

Fatmasari, Reni. (2013). Designing English Learning Modules for The Hidden Temples Tour Guides in Viavia Travel Agents. A thesis of Yogyakarta State University

Fitriani. (2017). Analyzing Students' Needs on the Content of Math English Materials in Math Education Department of UIN Alauddin Makassar. Unpublished Thesis. UIN Alauddin Makassar

Flowerdew, Lynne. (2013). Needs Analysis and Curriculum Development in ESP. In The Handbook of English for Specific Purposes, edited by Brian Paltridge and Sue Starfield, 325-346. Oxford: Wiley-Blackwell.

Gage, J., \& Prince, D. (1982). Vocational English: Preparing for a first Job. TESOL Quarterly, 16, 349-358.

Graves, K. (2000). Designing language courses. Boston: Heinle \& Heinle.

Hatch, Evelyn, and Farhady, Hossein. (1982). Research Design and Statistics for Applied Linguistics. Rowley: Nwebury House Publishers, INC.

Hutchinson, Tom, and Alan Waters. (1987). English for Specific Purposes: A learning Centred-Approach, New York: Cambrige University Press,.

Isfahani, Rizki. (2014). The Influence of SpongeBob SquarePants Cartoon Movie on Students' Speaking Skill at the Eleventh Grade of SMAN 11 Kota Tangerang. Jurnal Sosial Sains, 43-54

Isnaini, S. (2010). Implementasi Komunikasi Pemasaran Terpadu sebagai Penyampai Pesan Promosi Usaha Kecil Menengah ( UKM ) di Indonesia. Jurnal Masyarakat, Kebudayaan Dan Politik, 22(4), 324-332.

Nurpahmi, S. (2013). An Introduction to English for Specific Purposes: Alauddin University Press.

Paltridge, Brian, and Sue Starfield. (2013). The Handbook of English for Specific Purposes. USA: Wiley Blackwell,.

Platt, E. (1996). The vocational clasroom: A great place to learn English. Washington, D.C.: Center for Applied Linguistics.

Purwanto, Djoko. (2011). Komunikasi Bisnis. Jakarta

Rebecca, M.V, (2010), Advanced Vocabulary. Teaching: The problem of collection, RELC..Journal V

Richards, J. C. (2001). Curriculum development in language teaching. Cambridge: Cambridge University Press.

Richterich, R. and Chancerel, J.L. (1980). Identifying the Needs of Adults Learning a Foreign Language. Oxford: Pergamon Press

Scrivener, J. (2005). Learning Teaching: A Guidebook for English Language Teachers (2nd ed.). Oxford: Macmillan.

Suadnyani, Ni Wayan. (2009). Penerapan Strategi POWERS untuk Meningkatkan Keterampilan Menulis Argumentasi Mahasiswa Kelas X.A SMA Negeri 1 
Kubutambahan. Skripsi (tidak diterbitkan). Singaraja: Universitas Pendidikan Ganesha

Sugiyono. (2010). Metode Penelitian Pendidikan: Pendekatan Kuantitatif, Kualitatif, dan $R \& D$. Bandung: Alfabeta,.

Sudijono, Anas. (2003). Pengantar Statistik pendidikan. Jakarta: PT. Raja Grafindo Persada

Tarigan, Djago.dkk. (2011). Pengembangan Keterampilan Berbicara. Jakarta: Depdikbud Bagian Proyek Penataran Guru SLTP setara D III.

Tayie, S. (2005). Research Methods and Writing Research Proposals. Cairo: CAPSCU

The American heritage dictionary of the English language.

http://education.yahoo.com/reference/dictionary/entry/vocational\%20school

http://education.yahoo.com/encyclopedia/entry/entry/cvocatled accessed on $19^{\text {th }}$ August 2019.

Vogt, K., \& Kantelinen, R. (2013). Vocationally oriented language learning revisited. ELT Journal, 67 (1), 62-69

Waringin, T. D. (2008). Marketing Revolution. Jakarta: PT. Gramedia Pustaka Utama

Yilmaz, F. (2004). An English Language Needs Analysis of Preparatory Class Students at Gaziosmanpasa University. A Thesis. Bilkent University Ankara 